\title{
Routine cancer treatments and their impact on physical function, symptoms of cancer-related fatigue, anxiety, and depression
}

\author{
Niklas Paul Grusdat ${ }^{1}$ (D) Alexander Stäuber ${ }^{1} \cdot$ Marion Tolkmitt $^{2} \cdot$ Jens Schnabel ${ }^{2} \cdot$ Birgit Schubotz $^{3}$. \\ Peter Richard Wright ${ }^{4} \cdot$ Henry Schulz ${ }^{1}$
}

Received: 20 May 2021 / Accepted: 30 December 2021 / Published online: 11 January 2022

(c) The Author(s) 2022

\begin{abstract}
Background and purpose Breast cancer can be a major challenge for affected women. Knowledge of the physical function, symptoms of cancer-related fatigue, anxiety, and depression based on the cancer treatment may help to guide adequate support.

Methods For this prospective observational study, we collected data from seventy-nine women with a mean age $54.6 \pm 9.5$ years prior to the onset of breast cancer treatment (T0) and after (T1/T2). Handgrip strength test (HGS), six-minute walk test (6MWT), the phase angle (PhA), the hospital anxiety and depression scale (HADS), and functional assessment of chronic illness therapy-fatigue (FACIT-F) were used to collect data from four treatment subgroups SC, surgery + chemotherapy; SCR, surgery + chemotherapy + radiation therapy; SR, surgery + radiation therapy; and S, surgery.

Results A mixed ANOVA revealed a significant interaction between time and group for $\mathrm{PhA}, F=8.55, p<0.01$; HGS, $F=3.59, p<0.01$; 6MWT, $F=4.47, p<0.01$; and FACIT-F, $F=2.77, p<0.05$ with most pronounced deterioration seen in group SCR (PhA 4.8 ${ }^{\circ}$ HGS $27.5 \mathrm{~kg}$, 6MWT $453.4 \mathrm{~m}$, FACIT-F 33.8 points). HADS data displayed moderate anxiety and depression predominantly after treatment.

Conclusion Our study showed that the extent of change in physical function, symptoms of fatigue, anxiety, and depression depends on the treatment conditions. The potentially higher risk of impaired function due to the prevalence of values below a critical threshold requires early initiated multidisciplinary support.
\end{abstract}

Keywords Physical function $\cdot$ Mental health $\cdot$ Survivorship $\cdot$ Support

\section{Introduction}

Breast cancer continues to be the most frequently diagnosed female cancer in the USA [1]. The European Union reported 91,826 cases of death from breast cancer in 2020. About 70,000 new cases are diagnosed in Germany every year.

Niklas Paul Grusdat

niklas.grusdat@hsw.tu-chemnitz.de

1 Professorship of Sports Medicine/Sports Biology, Chemnitz University of Technology, Thüringer Weg 11, 09126 Chemnitz, Sachsen, Germany

2 Deutsches Rotes Kreuz Krankenhaus (DRK), German Red Cross Hospital, Chemnitz-Rabenstein, Germany

3 Tumorzentrum Chemnitz e.V., Clinical Cancer Registry, Chemnitz, Germany

4 Department of Sport, Health Sciences and Social Work, Oxford Brookes University, Oxford, UK
Overall survival has improved in recent decades with new therapy options and personalized medicine [2].

However, breast cancer patients receiving active treatment are often overwhelmed, resulting in various concerns [3]. Despite the underrepresentation in scientific research, social-emotional challenges [4], physical functional limitations [5, 6], experiences of depression [7], debilitating fears [8], and cancer-related fatigue (CRF) $[9,10]$ have been observed. If unmanaged, deficits may lead to impaired quality of life and the inability to handle instrumental activities of daily living [11, 12]. Especially at an early stage in life, the ability to function in the workplace and employment issues are of great concern [13]. Particularly in stages of cancer I-III, pronounced effects seem not adequately investigated and underestimated in routine clinical assessment. Moreover, a comprehensive patient-orientated picture on prevalence and severity of adverse events at diagnosis, across conventional treatment, and survivorship is lacking. 
Handgrip strength (HGS) [14] and the six-minute walk test (6MWT) [15] have gained scientific credibility in the clinical setting as biomarkers of physical function. In addition, the use of bioelectrical impedance analysis (BIA)-derived phase angle ( $\mathrm{PhA}$ ) led to scientific interest because it provides detailed information on body composition, general health [16], and cell membrane integrity [17]. These measures are of prognostic value for an unfavorable clinical outcome, e.g., disease progression [18] and the incidence of postoperative complications [19].

More studies are needed on patients' perceived circumstances linked to their routine cancer treatment, including chemotherapy, surgery, and radiation therapy. Alongside the traditional clinical reports, transparency on patient-reported outcomes (PROs) is required to enhance the quality of care $[20,21]$. Close monitoring patient's care pathway appears to be of particular relevance as the option to conduct a risk stratification becomes available. Differentiating the patient's perception of disease and detecting unmet supportive care needs could help personalize and optimize clinical and survivorship care. Few scientific data are available to establish critical threshold values of physical function combined with CRF, anxiety, and depression of women with breast cancer. The purpose of the present study was to determine the extent to which PROs of physical function, CRF, anxiety, and depression change throughout the treatment of breast cancer and in early survivorship.

\section{Methods}

Between April 2018 and October 2020, a total of 157 patients with the first diagnosis of breast cancer were recruited within the research study "Return" (trial acronym), which was approved by the ethics committee of Chemnitz University of Technology (V-182-17-AS-Tumor-20012017) and registered with the German Clinical Trials Register (ID: DRKS00014263). Patients were recruited in the Red Cross Hospital in Chemnitz-Rabenstein/Germany. Within 1 week after the breast cancer diagnosis, women were invited by their doctor to consultation and informed about possible participation in the present study. Participants had the opportunity to discuss their participation and consider the information leaflet with detailed information on the research process. Furthermore, sufficient time ( $>24 \mathrm{~h}$ ) to reflect on the implications of participating in the study was given before the patients had to decide. Inclusion criteria for this analysis were patients' written informed consent, recent diagnosis of untreated female breast cancer, age $<70$ years, no defibrillator or cardiac pacemaker, and no orthopedic restrictions for participating in the assessment. Patients were excluded after completing a medical history interview for eligibility if they had a previous invasive malignancy, other malignant tumors, untreated pulmonary hypertension, and chronic obstructive pulmonary disease. Eighty-seven participants who had not initiated cancer treatment met the inclusion criteria and completed the allocated assessments and medical interventions for statistical analysis of this prospective observational study. Eight patients were excluded from the analysis if lost to follow-up or due to missing values in the questionnaires. Further restrictions were recorded as presented in Fig. 1. Data were collected three times, prior to the onset of cancer treatment, at pre-test (T0), and after, at post-test (T1). To be able to keep the schedule, appointments were made immediately and in progress towards completion. The second follow-up (T2) was carried out approximately 3 months after medical treatment for each woman. Cases with longterm endocrine therapy continued beyond $\mathrm{T} 2$. Based on the variable duration of breast cancer treatment, repeated testing was performed at different times. Cooperation and coordination between parties involved were required to ensure participation. Four treatment subgroups were included for the following analysis (SC, Surgery + Chemotherapy; SCR, Surgery + Chemotherapy + Radiation Therapy; SR, Surgery + Radiation Therapy; S, Surgery). Baseline demographics, tumor pathology, estrogen receptor, progesterone receptor, and human epidermal growth factor receptor status were provided by the Clinical Cancer Registry Chemnitz (Tumorzentrum Chemnitz) (Table 1).

\section{Measurements}

Particular patients receiving cytotoxic drugs were reported to have difficulties performing complex assessments. Therefore, in order to address conditions, HGS test with a hydraulic hand dynamometer (Baseline ${ }^{\circledR}$, HIResTM, Gauge ERTM, USA) was performed. This test requires only a single piece of equipment and minimal effort to conclude muscle mass and muscle function (strength or physical performance) on subjects who may be unwilling or unable to execute other more strenuous tests. In general, it may be a measure of physical fitness as it predicts overall strength and health. Following the Southampton protocol [22], the subject was seated in a standard chair with legs, back support, and fixed arms (the same chair for each measurement), while the feet were placed flat on the floor with the hips and knees positioned at approximately $90^{\circ}$. The participant was instructed to maintain the shoulder slightly abducted (approximately $10^{\circ}$ ), elbow flexed at $90^{\circ}$, forearm in neutral position (rested on the arms of the chair), thumb facing upwards, and wrist just over the end of the arm of the chair (between $15^{\circ}$ and $30^{\circ}$ of extension and $0-15^{\circ}$ of ulnar deviation). A demonstration showed that gripping very tightly registers the best score. To ensure a comfortable feeling in 
Fig. 1 STROBE flow diagram of the prospective observational study in women with breast cancer

\section{Strobe Flow Diagram}

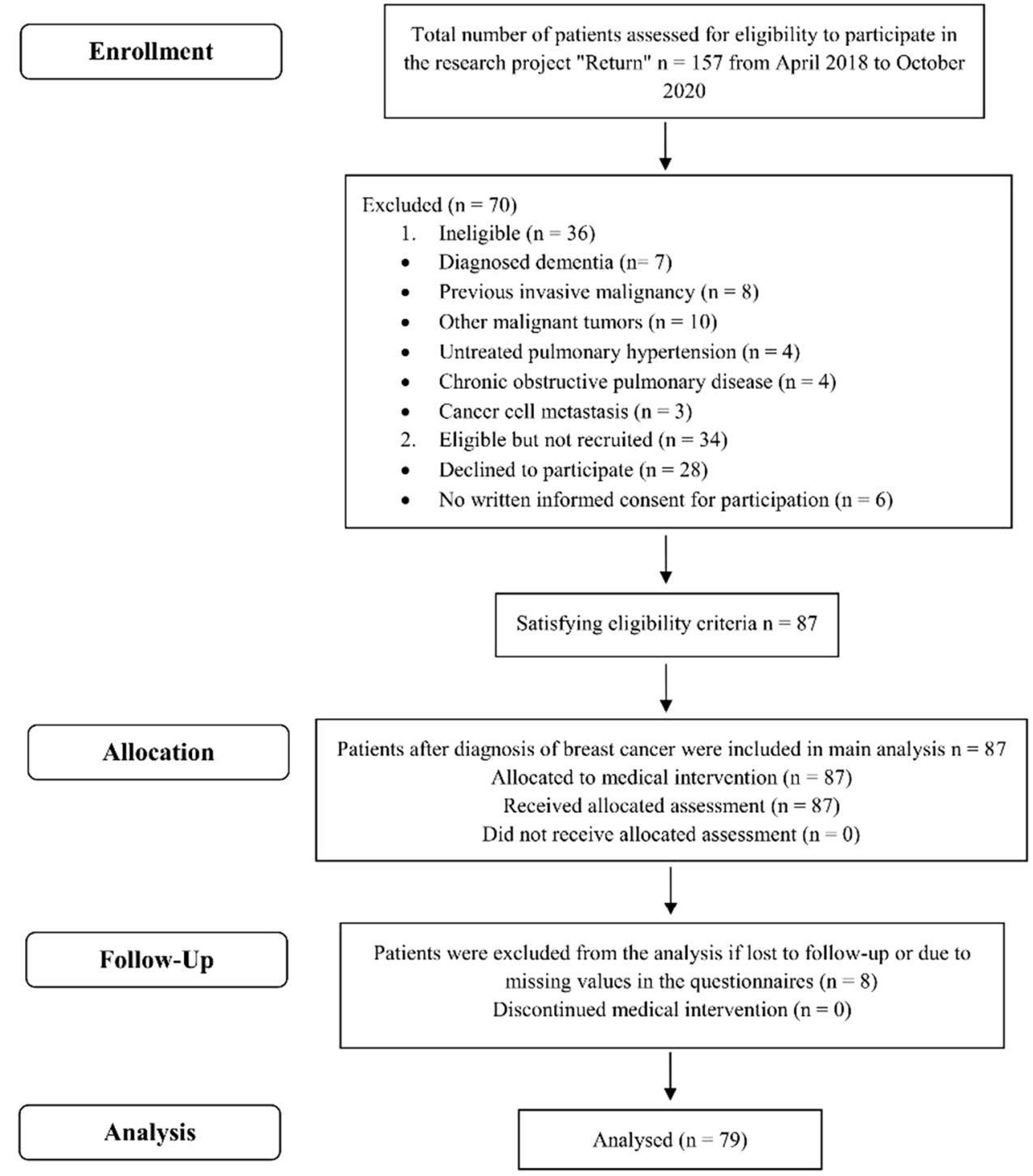

the hand, the bow handles' span was adjusted for the individually preferred length. Three trials on each side (alternating) of the right and left hand were performed, starting with the right hand. While holding the dynamometer, the base rested on the palm of the examinators hand. This supported the weight of the dynamometer to negate the effect of gravity on peak strength. Following the protocol, the participant was instructed: "I want you to squeeze as hard as you can for as long as you can until I say stop. Squeeze, squeeze, squeeze, stop" (when the needle stops rising). The maximum grip score (the peak value in kilograms from the outer dial) of all six attempts was used in statistical analyses.

The 6MWT is an evidence-based method to determine treatment effects on cancer patients' submaximal endurance performance and functional exercise capacity [16]. The valid and reliable measure was used to examine the most excellent possible walking distance on a 20-m (m) track in 6 min [23]. In line with standardization, under no circumstances was the pace increased beyond walking. Walking with other patients or the observer was prohibited for the examination. Prefabricated markings on the floor of the corridor served as route boundaries. An acoustic stop signal was signaling the completion of the test.

The $\mathrm{PhA}$ and raw impedance parameters of cell resistance $(\mathrm{R})$ and cell reactance $(\mathrm{Xc})$ were measured using BIA, a non-invasive technique to predict the body composition (BIA® $3 \mathrm{SF}$, EgoFit GmbH, Germany). After resting for $10 \mathrm{~min}$ in supine, the associated bio-signals of $\mathrm{R}, \mathrm{Xc}$, and the $\mathrm{PhA}$ were recorded on the subject's right side of the body, between the wrist and ankle via skin electrodes on a non-conductive surface. By applying a harmless, alternating current at a fixed frequency of $50 \mathrm{kHz}$, a homogeneous 
Table 1 Baseline demographics of $n=79$ women with breast cancer

\begin{tabular}{|c|c|c|c|c|}
\hline Variable & Group SC & Group SCR & Group SR & Group S \\
\hline$N(\%)$ & $22(27.9)$ & $17(21.5)$ & $27(34.2)$ & $13(16.5)$ \\
\hline Age [years] & $\begin{array}{l}51.9 \pm 11.6 \\
(30.0-69.0)\end{array}$ & $\begin{array}{l}54.4 \pm 8.5 \\
(41.0-64.0)\end{array}$ & $\begin{array}{l}56.7 \pm 9.0 \\
(40.0-69.0)\end{array}$ & $\begin{array}{l}55.3 \pm 7.3 \\
(46.0-64.0)\end{array}$ \\
\hline Age, $30-35$ years $n(\%)$ & $2(2.5)$ & $0(0.0)$ & $0(0.0)$ & $0(0.0)$ \\
\hline Age, $35-40$ years $n(\%)$ & $2(2.5)$ & $0(0.0)$ & $3(3.7)$ & $0(0.0)$ \\
\hline Age, $41-49$ years $n(\%)$ & $5(6.3)$ & $6(7.6)$ & $2(3.7)$ & $3(3.8)$ \\
\hline Age, $50-59$ years $n(\%)$ & $6(7.6)$ & $4(5.1)$ & $9(11.4)$ & $6(7.6)$ \\
\hline Age, $60-69$ years $n(\%)$ & $7(8.9)$ & $7(8.9)$ & $13(16.5)$ & $4(5.1)$ \\
\hline Height $[\mathrm{m}]$ & $\begin{array}{l}1.65 \pm 0.08 \\
(1.50-1.82)\end{array}$ & $\begin{array}{l}1.65 \pm 0.08 \\
(1.47-1.78)\end{array}$ & $\begin{array}{l}1.61 \pm 0.06 \\
(1.45-1.72)\end{array}$ & $\begin{array}{l}1.63 \pm 0.08 \\
(1.41-1.72)\end{array}$ \\
\hline Weight [kg] & $\begin{array}{l}72.1 \pm 14.2 \\
(55.7-107.9)\end{array}$ & $\begin{array}{l}82.7 \pm 20.2 \\
(54.1-135.1)\end{array}$ & $\begin{array}{l}68.6 \pm 12.4 \\
(49.3-95.9)\end{array}$ & $\begin{array}{l}72.6 \pm 12.5 \\
(46.9-97.5)\end{array}$ \\
\hline $\mathrm{BMI}\left[\mathrm{kg} \mathrm{m}^{-2}\right]$ & $\begin{array}{l}26.4 \pm 5.0 \\
(20.3-38.2)\end{array}$ & $\begin{array}{l}30.5 \pm 6.8 \\
(22.0-45.2)\end{array}$ & $\begin{array}{l}26.4 \pm 4.8 \\
(19.0-37.9)\end{array}$ & $\begin{array}{l}27.4 \pm 4.3 \\
(23.0-37.6)\end{array}$ \\
\hline $\begin{array}{l}\mathrm{UICC} \\
n(\%)\end{array}$ & $\begin{array}{l}\text { IA: } 5(6.3), \\
\text { IIA: } 10(12.7) \\
\text { IIIA: } 1(1.3) \\
\text { IIB: } 6(7.6)\end{array}$ & $\begin{array}{l}\text { IA: } 7(8.9) \text {, } \\
\text { IIA:7 }(8.9) \\
\text { IB: } 2(2.5) \\
\text { IIB: } 1(1.3)\end{array}$ & $\begin{array}{l}\text { IA: } 25(31.7), \\
\text { IIA: } 2(2.5) \\
\text { IB: } 0(0.0) \\
\text { IIB: } 0(0.0)\end{array}$ & $\begin{array}{l}\text { IA: } 5(6.3) \\
\text { IIA: } 8(10.1) \\
\text { IB: } 0(0.0) \\
\text { IIB: } 0(0.0)\end{array}$ \\
\hline $\begin{array}{l}\text { Her2/neu status, } \\
n(\%)\end{array}$ & $\begin{array}{l}\text { Pos. } 1 \text { (1.3) } \\
\text { Neg. } 21(26.6)\end{array}$ & $\begin{array}{l}\text { Pos. } 2(2.5) \\
\text { Neg. } 15(19.0)\end{array}$ & $\begin{array}{l}\text { Pos. } 0(0.0) \\
\text { Neg. } 27(34.2)\end{array}$ & $\begin{array}{l}\text { Pos. } 13(16.5) \\
\text { Neg. } 0(0.0)\end{array}$ \\
\hline $\begin{array}{l}\text { ER status, } \\
n(\%)\end{array}$ & $\begin{array}{l}\text { Pos. } 13 \text { (16.5) } \\
\text { Neg. } 9 \text { (11.4) }\end{array}$ & $\begin{array}{l}\text { Pos. } 14 \text { (17.7) } \\
\text { Neg. } 3 \text { (3.8) }\end{array}$ & $\begin{array}{l}\text { Pos. } 27(34.2) \\
\text { Neg. } 0(0.0)\end{array}$ & $\begin{array}{l}\text { Pos. } 13 \text { (16.5) } \\
\text { Neg. } 0(0.0)\end{array}$ \\
\hline $\mathrm{MC}, n(\%)$ & $1(1.3)$ & $1(1.3)$ & $0(0.0)$ & $0(0.0)$ \\
\hline IDC, $n(\%)$ & $18(22.8)$ & $16(20.3)$ & $24(30.4)$ & $7(8.9)$ \\
\hline IDC-L, $n(\%)$ & $0(0.0)$ & $0(0.0)$ & $0(0.0)$ & $1(1.3)$ \\
\hline ILC, $n(\%)$ & $3(3.8)$ & $0(0.0)$ & $2(2.5)$ & $5(6.3)$ \\
\hline $\mathrm{ICC}, n(\%)$ & $0(0.0)$ & $0(0.0)$ & $1(1.3)$ & $0(0.0)$ \\
\hline
\end{tabular}

Data are expressed as means \pm standard deviation (SD); minimum and maximum $n=$ number of patients (percentage)

$S C$, Surgery + Chemotherapy; $S C R$, Surgery + Chemotherapy + Radiation Therapy: SR, Surgery + Radiation Therapy; S, Surgery; ER, estrogen receptor; $H$ HER2/neu, human epidermal growth factor receptor 2; ICC, invasive cribriform carcinoma; IDC, invasive ductal carcinoma; $I D C$ - $L$, invasive ductal carcinoma with lobular features; $I L C$, invasive lobular carcinoma; $M C$, mucinous breast carcinoma; $n e g$, negative; pos, positive; UICC, Union for International Cancer Control electrical energy field was generated by which the conductivity of the human body was measured. The body water and the containing substances were causing a resistive ohmic resistance representing the tissue hydration status of intracellular and extracellular fluid. The electrical charges at the cell membranes were causing a capacitive resistance associated with the nutritional status, the body cell mass, membrane integrity, and skeletal muscle mass. The arctangent between $\mathrm{R}$ (pure opposition of a biological conductor) and Xc (capacitative) was computed by using the following equation: $P h A\left[^{\circ}\right]=\arctan \left(\frac{X c}{R}\right) \times\left(\frac{180}{\pi}\right)$. The PhA is the essential reference value and an indicator of health $[22,24]$.

Height and weight were measured with footwear and headwear removed using a standard stadiometer and weigh scale, Seca IEC 601 (Vogel \& Halke, Hamburg, Germany). This protocol allows the calculation of the body mass index (BMI). All assessments were performed by personnel trained in densitometry and blinded to the assignment. Mental health is investigated by the hospital anxiety and depression scale (HADS). Fatigue and the impact on daily activities and function were self-reported with the functional assessment of chronic illness therapy-fatigue (FACIT-F). All patients completed the questionnaires with qualified personnel available to answer any questions or clarify the meaning of any of the items.

\section{Questionnaires}

The hospital anxiety (HADS-A) and depression scale (HADS-D) consists of 14 thematically alternately listed questions (points per question: 0-3; total score 0-21). HADS-A and HADS-D are interpreted as follows: $0-7=$ normal, $8-10=$ borderline abnormal (mild case), $11-14=$ abnormal (moderate case), 15-21= abnormal (severe case). Higher HADS-values represent a more pronounced mental impairment [25]. To determine CRF, the 13-item functional assessment of chronic illness therapy-fatigue (FACIT-F) with a range from 0 to 52 was applied [26]. For FACIT-F, 
higher scores (negative items were reverse-scored) indicate a non-fatigued status.

\section{Data analysis}

For HGS [27], PhA [28], and 6MWT [29], data can be interpreted and classified in terms of their clinical relevance due to existing critical threshold values in the scientific literature. Critical grip strength is categorized by a value below the individual standardized mean risk threshold of $\geq 1$ SD [27]. For the global impedance parameter analysis, the fifth percentile, stratified for sex, age, and BMI, appears as a cutoff and reference for impaired functional status [28]. The sex-specific reference equation $6 M W D=2.11 \times$ height $\left._{c m}\right)-\left(2.29 \times\right.$ weight $\left._{\mathrm{kg}}\right)-(5.78 \times a g e)+667 \mathrm{~m}$ was used to compute and categorize the predicted walking distance (m) for the study individuals [29].

\section{Statistical analysis}

The data analysis was performed with the statistical software package IBM SPSS statistics 26 (Chicago, IL, USA). Only those patients who completed all assessments were included in the analysis. Descriptive statistics are presented as mean, standard deviation (SD), and the minimum and maximum of the outcome parameters. A significance level of $P<0.05$ was set. To avoid estimation problems, the authors were expecting a moderate to large effect size. The power level of analysis was set at 0.80 . Based upon pilot testing, the estimated sample size was sufficient to analyze group effects and significant differences. Demographic characteristics (age, height, weight, BMI) were tested using ANOVA to ensure comparability between the study groups. All metric data were normally distributed (Shapiro-Wilk test). Requirements for applying mixed ANOVA (between-within) were identified in terms of sphericity (Mauchly test) and variances equality (homogeneity) (Levene's test). A Bonferroni correction was applied to counteract the accumulation of alpha errors and estimation problems, avoiding the likelihood of incorrectly rejecting a null hypothesis (i.e., making a type I error). The main effects for time (entire group and individual groups), the interaction between time and group (difference between groups), and group comparison regardless of the time were tested for significant effects using a mixed ANOVA and post hoc analysis (Tukey, Games-Howell). The primary effect for time on the dependent variables (independently of the group allocation) was investigated with simple main effects of the within-subject factor (Greenhouse-Geisser). The time effect of the individual groups ([mean T0-mean T1, T2]/SD) was tested with a repeated measure analysis of variance for simple main effects of the betweensubjects factor (Tukey-HSD) [30]. The effect size was cal-

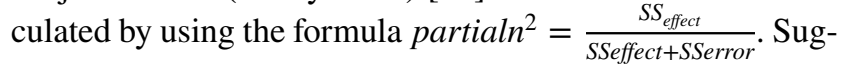

gested benchmarks for interpretation of the effect size are small (0.1-0.3), medium (0.3-0.5), and large (>0.5) [31].

\section{Results}

Seventy-nine women with breast cancer were included in the present analysis. The group distribution and patients' clinical characteristics, and the treatment time are summarized in Table 2. The response rate for patients that had been contacted to participate in this study was 55\% (the number of enrollees divided by the number of subjects screened). The mean (SD) age of the total sample at diagnosis was $54.6 \pm 9.5$ years (range $=30-69$ years). The mean (SD) time interval between diagnosis of breast cancer and initial data collection prior to starting treatment for breast cancer (T0) was $6.8 \pm 1.3$ days (range 6.0-9.0 days). Inclusion cutoff time for consent based on diagnosis was $4.5 \pm 1.2$ days (range 2.0-7.0 days). For completing treatment, all women with primary disease finished their cycles of chemotherapy, treatment sessions of radiation therapy, and/or cancer surgery. The total mean (SD) time for completing therapy was $6.6 \pm 3.0$ months (range 1.0-13.4 months). After the end of breast cancer treatment, data were collected within 1 week (mean $5.7 \pm 0.8$ days, range 4.0-7.0). The second follow-up for each patient took place 3 months after T1 (mean $91.4 \pm 1.5$ days, range 86.0-97.0).

\section{Anthropometrics and biomarkers of physical functional status}

The statistical comparison of the anthropometric data and the biomarkers of physical functional status is listed in Table 3. The numerical data of the longitudinal comparison indicated a significant main effect for the anthropometric parameters: weight $[\mathrm{kg}]$ and $\mathrm{BMI}\left[\mathrm{kg} / \mathrm{m}^{2}\right]$.

Functional status (HGS, 6MWT, PhA) was significantly reduced at $\mathrm{T} 1$ and $\mathrm{T} 2$, with more significant restrictions experienced in women exposed to chemotherapy.

The mean walking distance of $511.1 \mathrm{~m}$ (T0), $481.0 \mathrm{~m}$ (T1), and $485.9 \mathrm{~m} \mathrm{(T2)} \mathrm{for} \mathrm{the} \mathrm{entire} \mathrm{group} \mathrm{represents}$ low submaximal endurance performance. Considering the age of our study participants (54.6 \pm 9.5 years), the overall HGS $(\mathrm{T} 0=31.9 \mathrm{~kg}, \mathrm{~T} 1=28.0 \mathrm{~kg}, \mathrm{~T} 2=27.8 \mathrm{~kg})$ indicated a weak muscle strength. Medium to large effects for R, Xc, and $\mathrm{PhA}$ were meeting the criteria for abnormal physiology. The most pronounced impact on the state of health at T1 $\left(4.8^{\circ} \pm 0.5\right)$ in the SCR group represented a mean reduction of $1.1^{\circ}$ from baseline. 
Table 2 Clinical characteristics of $n=79$ breast cancer patients according to their routine cancer treatment

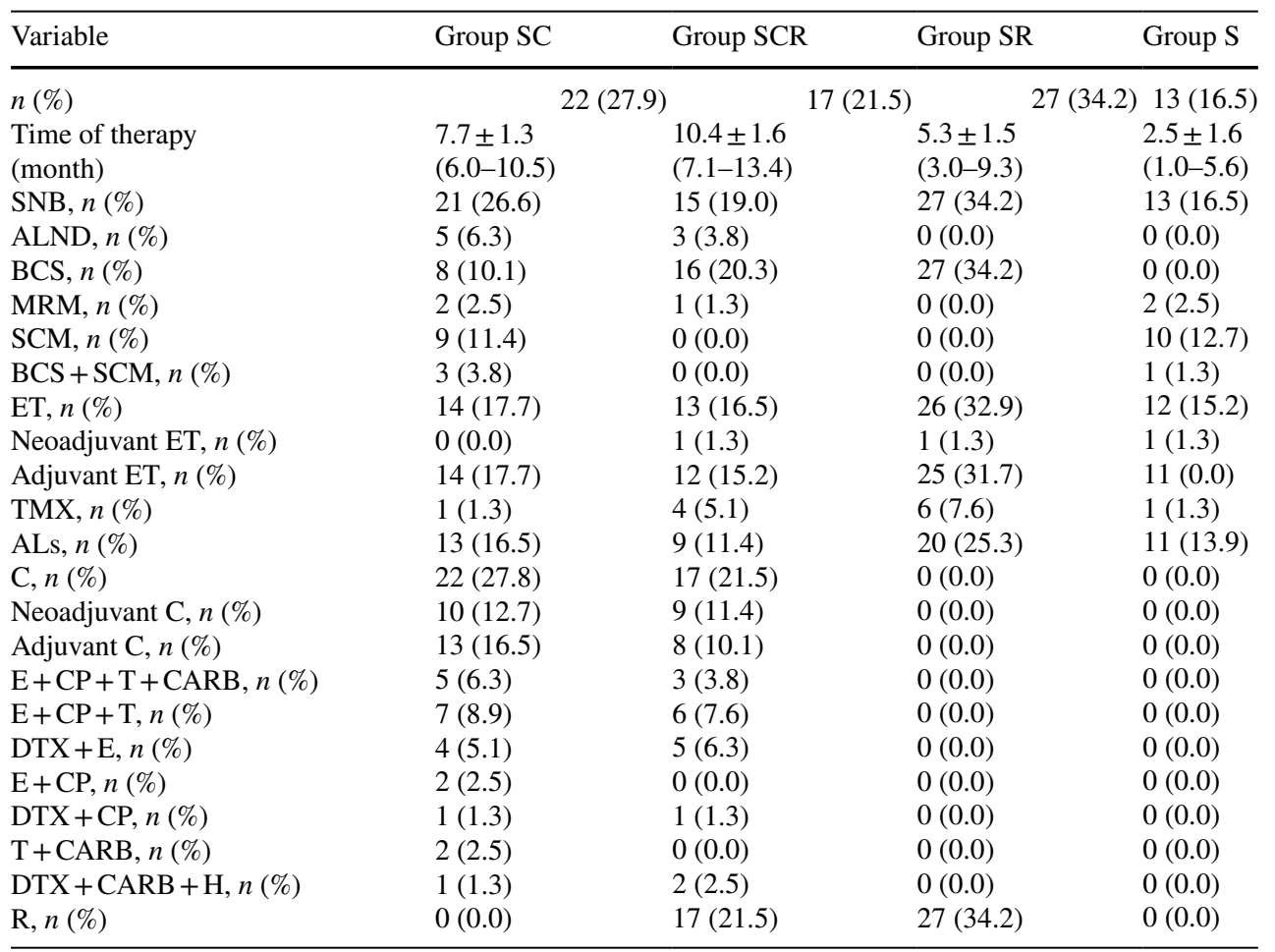

Data are expressed as means \pm standard deviation $(\mathrm{SD})$; min, minimum; max, maximum; $n=$ number of patients (percent)

$S C$, Surgery + Chemotherapy; $S C R$, Surgery + Chemotherapy + Radiation Therapy; $S R$, Surgery + Radiation Therapy; $S$, Surgery; $A L N D$, axillary lymph node dissection; $A L s$, aromatase inhibitors; $B C S$, breast-conserving surgery; $C A R B$, carboplatin; $C P$, cyclophosphamide; $C$, chemotherapy; $D T X$, docetaxel; $E$, epirubicin; $E T$, endocrine therapy; $H$, herceptin (trastuzumab); $M R M$, modified radical mastectomy; $R$, radiation therapy; $S C M$, subcutaneous mastectomy; $S N B$, sentinel node biopsy; $S$, surgery; $T$, paclitaxel; $T M X$, tamoxifen

\section{Physical function and the corresponding prevalence of critical values}

Substantial deteriorations were recognized post-cancer treatment in SC (91\%) and SCR (88\%) for a lower limit of the average range [29].

The mean HGS of $32.5 \mathrm{~kg}$ was above the risk threshold $(26.6 \mathrm{~kg})$ of a large German reference population, including healthy women aged 50-54 years. A detailed view on the study groups pointed out that $41 \%$ of women with SCR presented a critically HGS at T1, which decreased to $29 \%$ at T2 [27]. Although fewer patients showed values below the risk threshold at $\mathrm{T} 2$, a negative trend was detected. This may be explained by a further decline in patients already detected in a state of higher risk for possible future morbidity and mortality. At the same time, others showed a slight improvement in line with the cutoff [27].

Average biomarkers were shown before the onset of cancer treatment. Critical values below the published risk threshold were detected after breast cancer treatment and at second follow-up [28]. In order to examine thresholds at each time point, parameters were displayed in Table 4.

\section{Cancer-related fatigue}

The significant reduction in FACIT-F indicated the presence of experienced fatigue, with more severe conditions based on treatment using cytostatic agents and radiotherapy.

\section{Anxiety and depression}

Abnormal anxieties (moderate case), 38.0\% (T0), 62.0\% (T1), and $43.0 \%$ (T2), and depression (moderate case), $17.7 \%$ (T0), $36.7 \%$ (T1), and $34.2 \%$ (T2), were elucidated for the total group.

\section{Discussion}

Based on the preliminary data of the research study "Return," we conducted a sub-analysis of the PRO measures of functional and mental status and the state of CRF in women with breast cancer regarding their routine cancer treatment. Clinically established assessment procedures were used prior to the onset of (T0) and post-cancer 
Table 3 The primary outcome measures of anthropometrics, physical function, fatigue, anxiety, and depression of the subgroups prior to the onset of (T0), after cancer treatment (T1), and at second follow-up (T2)

\begin{tabular}{|c|c|c|c|c|c|c|c|c|c|c|c|}
\hline Variable & $\mathrm{G}$ & $\begin{array}{l}\text { Mean (SD) } \\
\text { T0 }\end{array}$ & $\mathrm{T} 1$ & $\mathrm{~T} 2$ & $\mathrm{n}$ & $P^{*}-\mathrm{T}$ & $F-\mathrm{T}$ & $F-\mathrm{G}$ & $F-\mathrm{GxT}$ & $\begin{array}{l}\eta^{2} \\
(\mathrm{~T})\end{array}$ & $\begin{array}{l}\eta^{2} \\
(\mathrm{GxT})\end{array}$ \\
\hline Weight [kg] & $\begin{array}{l}\text { SC } \\
\text { SCR } \\
\text { SR } \\
\text { S }\end{array}$ & $\begin{array}{l}72.1 \pm 14.2 \\
82.7 \pm 20.24 \\
68.6 \pm 12.4 \\
72.6 \pm 12.5\end{array}$ & $\begin{array}{l}69.8 \pm 13.7 \\
80.1 \pm 21.3 \\
67.4 \pm 12.2 \\
71.3 \pm 12.3\end{array}$ & $\begin{array}{l}71.8 \pm 13.9 \\
80.4 \pm 20.1 \\
67.9 \pm 11.7 \\
71.4 \pm 12.4\end{array}$ & $\begin{array}{l}22 \\
17 \\
27 \\
13\end{array}$ & $\begin{array}{l}a, c \\
a, b \\
a\end{array}$ & $11.98^{* * *}$ & $2.84^{*}$ & 1.18 & 0.14 & 0.05 \\
\hline $\begin{array}{l}\text { BMI } \\
{\left[\mathrm{kg} \mathrm{m}^{-2}\right]}\end{array}$ & $\begin{array}{l}\text { SC } \\
\text { SCR } \\
\text { SR } \\
\text { S }\end{array}$ & $\begin{array}{l}26.4 \pm 5.0 \\
30.5 \pm 6.8 \\
26.4 \pm 4.8 \\
27.4 \pm 4.3\end{array}$ & $\begin{array}{l}25.6 \pm 4.8 \\
29.5 \pm 7.0 \\
25.9 \pm 4.8 \\
26.9 \pm 4.1\end{array}$ & $\begin{array}{l}26.3 \pm 4.8 \\
29.6 \pm 6.6 \\
26.1 \pm 4.4 \\
26.9 \pm 4.2\end{array}$ & $\begin{array}{l}22 \\
17 \\
27 \\
13\end{array}$ & $\begin{array}{l}a, c \\
a, b \\
a\end{array}$ & $12.46^{* * *}$ & 2.23 & 1.15 & 0.14 & 0.04 \\
\hline $\begin{array}{l}\text { R } 50 \\
\text { kHz [Ohm] }\end{array}$ & $\begin{array}{l}\text { SC } \\
\text { SCR } \\
\text { SR } \\
\text { S }\end{array}$ & $\begin{array}{l}556.4 \pm 59.1 \\
514.9 \pm 59.7 \\
559.0 \pm 47.1 \\
529.5 \pm 33.6\end{array}$ & $\begin{array}{l}582.7 \pm 57.8 \\
546.2 \pm 60.2 \\
574.9 \pm 55.6 \\
532.2 \pm 41.2\end{array}$ & $\begin{array}{l}570.1 \pm 55.7 \\
532.7 \pm 59.1 \\
566.4 \pm 47.0 \\
525.1 \pm 41.3\end{array}$ & $\begin{array}{l}22 \\
17 \\
27 \\
13\end{array}$ & $\begin{array}{l}a, b, c \\
a, b, c \\
a\end{array}$ & $37.76^{* * *}$ & $3.35^{*}$ & $3.80^{* *}$ & 0.34 & 0.13 \\
\hline Xc 50 kHz [Ohm] & $\begin{array}{l}\text { SC } \\
\text { SCR } \\
\text { SR } \\
\text { S }\end{array}$ & $\begin{array}{l}55.0 \pm 7.2 \\
53.0 \pm 7.7 \\
53.0 \pm 6.0 \\
51.3 \pm 6.8\end{array}$ & $\begin{array}{l}48.6 \pm 7.1 \\
45.9 \pm 6.9 \\
47.5 \pm 4.9 \\
47.6 \pm 6.9\end{array}$ & $\begin{array}{l}50.4 \pm 6.4 \\
46.6 \pm 6.6 \\
50.4 \pm 5.5 \\
49.5 \pm 6.5\end{array}$ & $\begin{array}{l}22 \\
17 \\
27 \\
13\end{array}$ & $\begin{array}{l}\text { a, b, c } \\
\text { a, b } \\
\text { a, b, c } \\
\text { a, c }\end{array}$ & $130.96^{* * * *}$ & $0.71^{\mathrm{NS}}$ & $4.51^{* *}$ & 0.64 & 0.15 \\
\hline $\begin{array}{l}\mathrm{PhA} \\
50 \mathrm{kHz}\left[{ }^{\circ}\right]\end{array}$ & $\begin{array}{l}\text { SC } \\
\text { SCR } \\
\text { SR } \\
\text { S }\end{array}$ & $\begin{array}{l}5.6 \pm 0.6 \\
5.9 \pm 0.5 \\
5.4 \pm 0.6 \\
5.5 \pm 0.6\end{array}$ & $\begin{array}{l}4.8 \pm 0.5 \\
4.8 \pm 0.5 \\
4.7 \pm 0.5 \\
5.1 \pm 0.6\end{array}$ & $\begin{array}{l}5.1 \pm 0.5 \\
5.0 \pm 0.5 \\
5.1 \pm 0.6 \\
5.4 \pm 0.6\end{array}$ & $\begin{array}{l}22 \\
17 \\
27 \\
13\end{array}$ & $\begin{array}{l}\text { a, b, c } \\
\text { a, b } \\
\text { a, b, c } \\
\text { a, c }\end{array}$ & $188.86^{* * *}$ & $0.78^{\mathrm{NS}}$ & $8.55^{* * *}$ & 0.72 & 0.26 \\
\hline $\begin{array}{l}\text { HGS } \\
\text { peak } \\
{[\mathrm{kg}]}\end{array}$ & $\begin{array}{l}\text { SC } \\
\text { SCR } \\
\text { SR } \\
\text { S }\end{array}$ & $\begin{array}{l}32.7 \pm 3.9 \\
32.6 \pm 6.0 \\
31.4 \pm 3.2 \\
30.8 \pm 3.8\end{array}$ & $\begin{array}{l}27.8 \pm 4.5 \\
27.5 \pm 5.1 \\
28.4 \pm 3.3 \\
28.3 \pm 3.5\end{array}$ & $\begin{array}{l}27.9 \pm 4.9 \\
27.2 \pm 5.4 \\
28.3 \pm 3.1 \\
27.5 \pm 3.5\end{array}$ & $\begin{array}{l}22 \\
17 \\
27 \\
13\end{array}$ & $\begin{array}{l}a, b \\
a, b \\
a, b \\
a, b\end{array}$ & $139.06^{* * *}$ & $0.07^{\mathrm{NS}}$ & $3.59^{* *}$ & 0.65 & 0.25 \\
\hline $\begin{array}{l}\text { 6MWD } \\
{[\mathrm{m}]}\end{array}$ & $\begin{array}{l}\text { SC } \\
\text { SCR } \\
\text { SR } \\
\text { S }\end{array}$ & $\begin{array}{l}514.6 \pm 54.3 \\
493.3 \pm 56.7 \\
510.3 \pm 59.4 \\
529.9 \pm 59.9\end{array}$ & $\begin{array}{l}474.3 \pm 60.6 \\
453.4 \pm 66.2 \\
487.8 \pm 53.0 \\
514.0 \pm 61.7\end{array}$ & $\begin{array}{l}479.1 \pm 57.3 \\
460.5 \pm 60.6 \\
492.1 \pm 51.8 \\
517.6 \pm 53.4\end{array}$ & $\begin{array}{l}22 \\
17 \\
27 \\
13\end{array}$ & $\begin{array}{l}a, b \\
a, b \\
a, b \\
a, b\end{array}$ & $99.12^{* * * *}$ & $2.11^{\mathrm{NS}}$ & $4.47^{* *}$ & 0.57 & 0.15 \\
\hline $\begin{array}{l}\text { FACIT-F } \\
(0-52)\end{array}$ & $\begin{array}{l}\text { SC } \\
\text { SCR } \\
\text { SR } \\
\text { S }\end{array}$ & $\begin{array}{l}45.2 \pm 2.8 \\
44.9 \pm 2.8 \\
45.1 \pm 4.0 \\
45.8 \pm 5.2\end{array}$ & $\begin{array}{l}34.5 \pm 2.8 \\
33.8 \pm 2.9 \\
36.6 \pm 4.9 \\
37.2 \pm 4.3\end{array}$ & $\begin{array}{l}36.2 \pm 4.3 \\
35.2 \pm 3.9 \\
38.9 \pm 5.9 \\
39.9 \pm 4.4\end{array}$ & $\begin{array}{l}22 \\
17 \\
27 \\
13\end{array}$ & $\begin{array}{l}a, b \\
a, b \\
a, b, c \\
a, b, c\end{array}$ & $288.87^{* * *}$ & $2.56^{\mathrm{NS}}$ & $2.77^{*}$ & 0.79 & 0.10 \\
\hline $\begin{array}{l}\text { HADS-A } \\
(0-21)\end{array}$ & $\begin{array}{l}\text { SC } \\
\text { SCR } \\
\text { SR } \\
\text { S }\end{array}$ & $\begin{array}{l}8,8 \pm 3.4 \\
9.0 \pm 2.9 \\
9,2 \pm 4.0 \\
8,3 \pm 3.7\end{array}$ & $\begin{array}{l}11,3 \pm 3.0 \\
12,6 \pm 2.3 \\
10,4 \pm 2.8 \\
9,8 \pm 2.7\end{array}$ & $\begin{array}{l}10.8 \pm 2.9 \\
12.1 \pm 2.7 \\
9.9 \pm 2.7 \\
9.2 \pm 4.0\end{array}$ & $\begin{array}{l}22 \\
17 \\
27 \\
13\end{array}$ & $\begin{array}{l}a, b \\
a, b\end{array}$ & $18.68^{* * *}$ & $1.92^{\mathrm{NS}}$ & $1.51^{\mathrm{NS}}$ & 0.20 & 0.06 \\
\hline $\begin{array}{l}\text { HADS-D } \\
(0-21)\end{array}$ & $\begin{array}{l}\text { SC } \\
\text { SCR } \\
\text { SR } \\
\text { S }\end{array}$ & $\begin{array}{l}6.5 \pm 2.9 \\
6.8 \pm 3.8 \\
6.9 \pm 4.0 \\
7.1 \pm 4.6\end{array}$ & $\begin{array}{l}9.6 \pm 3.8 \\
10.5 \pm 3.0 \\
9.0 \pm 3.3 \\
8.4 \pm 3.6\end{array}$ & $\begin{array}{l}9.6 \pm 2.9 \\
10.1 \pm 4.1 \\
8.3 \pm 3.3 \\
8.1 \pm 3.6\end{array}$ & $\begin{array}{l}22 \\
17 \\
27 \\
13\end{array}$ & $\begin{array}{l}a, b \\
a, b \\
a \\
a\end{array}$ & $18.14^{* * *}$ & $0.60^{\mathrm{NS}}$ & $1.02^{\mathrm{NS}}$ & 0.20 & 0.04 \\
\hline
\end{tabular}

Data are expressed as means \pm standard deviation $(\mathrm{SD})$; change in percent $(\%)$

$S C$, Surgery + Chemotherapy; $S C R$, Surgery + Chemotherapy + Radiation Therapy; SR, Surgery + Radiation Therapy; $S$, Surgery; $n$, number of patients; $N S$, not significant; $T$, time; $G$, group

${ }^{*} P<0.05 ;{ }^{* *} P<0.01 ;{ }^{* * *} P<0.001$

a, T1 differed significantly from baseline; $b, T 2$ differed significantly from baseline; c, T2 differed significantly from T1

treatment $(\mathrm{T} 1, \mathrm{~T} 2)$. Our main findings provide evidence that women with breast cancer showed reduced physical function, mental health, and symptoms of fatigue after breast cancer diagnosis with significant deterioration following treatment. A potentially higher risk of impairment accompanied this due to the prevalence of values below a critical threshold. Across all groups, the most pronounced impact was found in patients with multimodular conditions.

Women receiving anticancer treatment may get overwhelmed by physical functional changes and emotional challenges. Possibly the PhA can be used as a global marker of health status. Available reference values of healthy adults $(n=214,732)$ across the lifespan (ages 
Table 4 The prevalence of critical values of bio-impedance phase angle, handgrip strength, and six-minute walk test prior to the onset of (T0), after cancer treatment (T1), and at second follow-up (T2)

\begin{tabular}{|c|c|c|c|c|}
\hline Variable & Group & T0 & $\mathrm{T} 1$ & $\mathrm{~T} 2$ \\
\hline \multirow[t]{4}{*}{$\begin{array}{l}\text { Below risk threshold, } \\
\mathrm{PhA}, n(\%)\end{array}$} & $\mathrm{SC}$ & $\begin{array}{l}\text { Yes }=1(4.5) \\
\text { No }=21(95.5)\end{array}$ & $\begin{array}{l}\text { Yes }=11(50.0) \\
\text { No }=11(50.0)\end{array}$ & $\begin{array}{l}\text { Yes }=5(22.7) \\
\text { No=17(77.3) }\end{array}$ \\
\hline & SCR & $\begin{array}{l}\text { Yes }=0(0.0) \\
\text { No }=17(100.0)\end{array}$ & $\begin{array}{l}\text { Yes }=9(52.9) \\
\text { No }=8(47.1)\end{array}$ & $\begin{array}{l}\text { Yes }=5(29.4) \\
\text { No }=12(70.6)\end{array}$ \\
\hline & SR & $\begin{array}{l}\text { Yes }=3(11.1) \\
\text { No }=24(88.9)\end{array}$ & $\begin{array}{l}\text { Yes }=13(48.1) \\
\text { No }=14(51.9)\end{array}$ & $\begin{array}{l}\text { Yes }=7(25.9) \\
\text { No }=20(74.1)\end{array}$ \\
\hline & S & $\begin{array}{l}\text { Yes }=1(7.7) \\
\text { No }=12(92.3)\end{array}$ & $\begin{array}{l}\text { Yes }=3(23.1) \\
\text { No }=10(76.9)\end{array}$ & $\begin{array}{l}\text { Yes }=1(7.7) \\
\text { No }=12(92.3)\end{array}$ \\
\hline \multirow[t]{4}{*}{$\begin{array}{l}\text { Below risk threshold, } \\
\text { HGS, } n(\%)\end{array}$} & $\mathrm{SC}$ & $\begin{array}{l}\text { Yes }=0(0.0) \\
\text { No }=22(100.0)\end{array}$ & $\begin{array}{l}\text { Yes }=7(31.8) \\
\text { No }=15(68.2)\end{array}$ & $\begin{array}{l}\text { Yes }=6(27.3) \\
\text { No }=16(72.7)\end{array}$ \\
\hline & SCR & $\begin{array}{l}\text { Yes }=1(5.9) \\
\text { No }=16(94.1)\end{array}$ & $\begin{array}{l}\text { Yes }=7(41.2) \\
\text { No }=10(58.8)\end{array}$ & $\begin{array}{l}\text { Yes }=5(29.4) \\
\text { No=12(70.6) }\end{array}$ \\
\hline & SR & $\begin{array}{l}\text { Yes }=1(3.7) \\
\text { No }=26(96.3)\end{array}$ & $\begin{array}{l}\text { Yes }=8(29.6) \\
\text { No }=19(70.4)\end{array}$ & $\begin{array}{l}\text { Yes }=7(25.9) \\
\text { No }=20(74.1)\end{array}$ \\
\hline & $\mathrm{S}$ & $\begin{array}{l}\text { Yes }=0(0.0) \\
\text { No }=13(100.0)\end{array}$ & $\begin{array}{l}\text { Yes }=6(46.2) \\
\text { No }=7(53.8)\end{array}$ & $\begin{array}{l}\text { Yes }=5(38.5) \\
\mathrm{No}=8(61.5)\end{array}$ \\
\hline \multirow[t]{4}{*}{$\begin{array}{l}\text { Below reference, } \\
6 \mathrm{MWT}, n(\%)\end{array}$} & SC & $\begin{array}{l}\text { Yes }=13(59.1) \\
\text { No=9(40.9) }\end{array}$ & $\begin{array}{l}\text { Yes }=20(90.9) \\
\text { No }=2(9.1)\end{array}$ & $\begin{array}{l}\text { Yes }=17(77.3) \\
\text { No }=5(22.7)\end{array}$ \\
\hline & SCR & $\begin{array}{l}\text { Yes }=11(64.7) \\
\text { No }=6(35.3)\end{array}$ & $\begin{array}{l}\text { Yes }=15(88.2) \\
\text { No }=2(11.8)\end{array}$ & $\begin{array}{l}\text { Yes }=12(70.6) \\
\mathrm{No}=5(29.4)\end{array}$ \\
\hline & SR & $\begin{array}{l}\text { Yes }=13(48.1) \\
\text { No }=14(51.9)\end{array}$ & $\begin{array}{l}\text { Yes }=20(74.1) \\
\mathrm{No}=7(25.9)\end{array}$ & $\begin{array}{l}\text { Yes }=15(55.6) \\
\text { No }=12(44.4)\end{array}$ \\
\hline & S & $\begin{array}{l}\text { Yes }=5(38.5) \\
\mathrm{No}=8(61.5)\end{array}$ & $\begin{array}{l}\text { Yes }=8(61.5) \\
\mathrm{No}=5(38.5\end{array}$ & $\begin{array}{l}\text { Yes }=6(46.2) \\
\text { No }=7(53.8)\end{array}$ \\
\hline
\end{tabular}

Data are expressed as $n=$ number of patients (percentage) for each group

$S C$, Surgery + Chemotherapy; $S C R$, Surgery + Chemotherapy + Radiation Therapy; $S R$, Surgery + Radiation Therapy; $S$, Surgery
18-70 years) facilitate the interpretation and classification of impedance parameters [28]. According to existing literature, reduced quality of life and impaired functional status are prevalent with risk threshold [28, 32, 33]. In the presented study, the evaluated changes in predicted body composition indicated unfavorable physiology. The decreased body cell mass and increased extracellular mass leading to low PhA may be evidence of clinically relevant malnutrition and functional loss (skeletal muscles) [24]. The valuable global biomarker is positively associated with Xc and negatively associated with $\mathrm{R}$. The significant change in Xc represents the resistive effect produced by the tissue interfaces and cell membranes, suggesting a reduction of membrane function and fewer intact numbers of cells [34]. $\mathrm{R}$ as the flow restriction to an electrical current implied a higher water distribution between the extraand intracellular compartments [35]. The observed state of fluid overload may be due to secondary lymphedema attributed to cancer-specific drug and surgical treatment [36-38]. Women who have lymph node removal followed by radiation therapy have a greater risk of developing swelling (e.g., arms and legs) caused by the congestion of lymph fluid. Taking part in regular physical activity stimulates lymphatic circulation and is therefore recommended [39]. Research on bio-electrical characteristics in connection with physical training initiated early in breast cancer treatment is needed.

The BIA is reliable and easily applicable for an oncology nurse or physiotherapist, as no special training is required. The portable use in various settings and quick feasibility allows long-term monitoring and identification of patients at risk. If accompanied by circadian-related measures, causal inference on insufficient dietary intake, body composition, and daily sleep and activity patterns may be improved [40, 41].

Weak physical performance status and concurrent cancer-related symptoms warrant examination. Limited muscle strength might impair the upper extremities' functionality and performance of everyday tasks (e.g., the ability to dress, write, or lift small objects) [42, 43]. Findings in patients exposed to anthracycline-taxane-containing chemotherapy could potentially be consistent with peripheral neuropathy and perceived loss of motor function, which can be particularly severe and long-lasting [44]. Besides the potentially life-threatening danger, women with breast cancer face various concerns of possible future challenges (e.g., familial, professional, sexuality, body image, logistical) [45]. Considering associations between the stressful life event and the low physical state raises the potential for a skewed rating affected by motivational and emotional aspects and 
psychological health [46, 47]. Other underlying mechanisms with possible modifying effects comprise general anesthesia received [48], changes in hormone levels [49], and chronic illness with painful or weak hands $[50,51]$. The detected continuous reduced functioning requires close observance beyond the time frame chosen in this study to prevent further decline. Early implementation of routine physical function tests may help health care professionals provide feedback and educated advice about the benefits of physical activity, e.g., resistance training.

Surprisingly, even pre-cancer treatment, retrenchment was detected and may be attributable to certain lifestyle factors, including diet, physical activity, smoking, and alcohol consumption [52]. A healthy individual's 6MWD ranges from 400 to $700 \mathrm{~m}(\mathrm{~m})$ and reflects the exercise capacity for daily physical activities [15]. Overall aerobic capacity may indicate the inability to meet job requirements to secure financial stability $[53,54]$. The cardiorespiratory fitness of affected women may be enhanced with moderate to vigorous physical activity (MVPA) of at least 150 min per week $[52,55]$.

The German general population-based FACIT-F norm of women aged 50-59 years with a mean score of 42.6 indicated the presence of fatigue in our study population [56]. Intense fatigue (e.g., "I have to limit my social activity because I am tired") was experienced by most women posttreatment. Severity is shaped by more significant pain, sleep disruption, distress, lower activity, and lower physical and social health status [55]. Furthermore, the proposed CRF is marked by increased lifestyle stresses, such as lack of ability to work and child or elderly care, and potentiated by the treatment time and younger age. For a holistic approach to reduce symptoms, a multidisciplinary support intervention program should contain pain therapy [57], nutritional medicine [58], and exercise therapy [59,60].

Mental impairment of anxiety and depression was linked to early stages of cancer (stages I-III). Especially, combination therapy evoked restlessness and tension with moderate to severe expression. It is difficult to distinguish between a timely fearful reaction and an anxiety symptom that requires intervention. Therapy appears to be necessary if the behavior and experience of the patients' everyday lives are impaired. Often, anxiety disorders or depression are not recognized or dismissed as an understandable reaction to a life-threatening illness. Promoting social support, particularly emotional support from family, may positively impact psychological stress and psychiatric morbidity [61]. For more clarity, routine assessments of psychiatric morbidities need to achieve widespread implementation in oncological care. By identifying those patients who require psycho-social support, therapeutic outcomes may be improved. A more substantial alignment with worries about the deterioration of conditions is favored, while the attitude of helplessness or hopelessness is associated with poorer breast cancer prognosis [62]. Women need to receive information about the adverse effects of cancer treatment and advice about coping methods [63, 64].

The present study adds to the existing literature on patient experiences of cancer care. A clear benefit was that patientorientated indicators and critical points of interest could be assessed quickly and easily with accepted measures. By carefully comprehending patients' treatment conditions, prospective capturing of perceived circumstances may be improved. Study designs must employ baseline testing to detect changes accurately. PROs may give health care professionals and the multidisciplinary team involved, including oncologists, physiotherapists, and nurses, guidance to determine individualized needs. Practical support in subsequent oncological rehabilitation treatment requires the most appropriate modalities and timing for initiation.

\section{Limitations}

There are limitations to the present study as we could not include an additional follow-up analysis. Since the number of patients, especially in group $\mathrm{S}$, was small $(n=13)$, our findings can only be regarded as preliminary, and future investigations are necessary for the generalizability of our findings. Treatment groups may not represent all cancer patients and especially not for those with severe course of illness. Socioeconomic status as a possible influencing factor was not investigated. Screening patients for their physical activity levels may have led to a more differentiated assumption of study results.

\section{Conclusion}

In summary, women with breast cancer showed decreased physical function, mental health, and symptoms of fatigue. Across all groups, the most pronounced impact was found in patients with multi-modular conditions. A potentially higher risk of impaired function accompanied this due to the prevalence of values below a critical threshold. Group differences were particularly noticeable in the reduced HGS, 6MWT, PhA, mental status, and in the heightened state of fatigue. Based on our findings, multidisciplinary support initiated early in breast cancer treatment seems appropriate to address conditions. The permanent adoption of PROs in clinical research increases the transparency of patients' perceived circumstances. Routine assessment may lead to an individual risk stratification, which could help personalize and optimize clinical and survivorship care.

Author contribution N.P.G. performed data collection, management, analysis, and manuscript writing; A.S. helped in data analysis and 
manuscript editing and provided scientific oversight; M.T. and J.S. helped in data collection; B.S. supplied clinical data and performed data management; P.R.W. and H.S. provided editorial assistance for the manuscript. All authors have read and approved the final manuscript.

Funding Open Access funding enabled and organized by Projekt DEAL.

Data availability The datasets used and/or analyzed during the current study are available from the corresponding author on reasonable request.

\section{Code availability N/A.}

\section{Declarations}

Ethics approval This study was performed in line with the principles of the Declaration of Helsinki. Approval was granted by the Ethics Committee of Chemnitz University of Technology (V-182-17-ASTumor-20012017). Written informed consent was obtained from all individual participants included in this study.

Consent to participate Patients' written informed consent to participate was obtained.

\section{Consent for publication N/A}

Conflict of interest The authors declare no competing interests.

Open Access This article is licensed under a Creative Commons Attribution 4.0 International License, which permits use, sharing, adaptation, distribution and reproduction in any medium or format, as long as you give appropriate credit to the original author(s) and the source, provide a link to the Creative Commons licence, and indicate if changes were made. The images or other third party material in this article are included in the article's Creative Commons licence, unless indicated otherwise in a credit line to the material. If material is not included in the article's Creative Commons licence and your intended use is not permitted by statutory regulation or exceeds the permitted use, you will need to obtain permission directly from the copyright holder. To view a copy of this licence, visit http://creativecommons.org/licenses/by/4.0/.

\section{References}

1. Siegel RL, Miller KD, Fuchs HE (2021) Jemal A (2021) Cancer statistics. CA Cancer J Clin 71(1):7-33. https://doi.org/10.3322/ caac. 21654

2. Barnes B, Kraywinkel K, Nowossadeck E, Schönfeld I, Starker A, Wienecke A, Wolf U (2016) Bericht zum Krebsgeschehen in Deutschland 2016. Robert Koch-Institut. https://doi.org/10.17886/ rkipubl-2016-014

3. Corey B, Smania MA, Spotts H, Andersen M (2020) Young women with breast cancer: treatment, care, and nursing implications. Clin J Oncol Nurs 24(2):139-147

4. Thorn DR, Ladewig Hess AR (2021) Outpatient breast cancer treatment after the hospital: what's next?-adjuvant medical therapies, management of side effects and common fears, planing and coordination of optimal follow-up care in view of current guidelines. Therapeutische Umschau Revue Therapeutique 78(3):136-144
5. Kubo Y, Naito T, Mori K, Osawa G, Aruga E (2017) Skeletal muscle loss and prognosis of breast cancer patients. Support Care Cancer 25(7):2221-2227

6. Ten Tusscher M, Groen W, Geleijn E, Sonke G, Konings I, Van der Vorst M, van Zweeden A, Aaronson N, Stuiver MM (2019) Physical problems, functional limitations, and preferences for physical therapist-guided exercise programs among Dutch patients with metastatic breast cancer: a mixed methods study. Support Care Cancer 27(8):3061-3070

7. Härtl K, Engel J, Herschbach P, Reinecker H, Sommer H, Friese K (2010) Personality traits and psychosocial stress: quality of life over 2 years following breast cancer diagnosis and psychological impact factors. Psycho-Oncology: J Psychol Soc Behav Dimens Cancer 19(2):160-169

8. Koch L, Bertram H, Eberle A, Holleczek B, Schmid-Höpfner S, Waldmann A, Zeissig SR, Brenner H, Arndt V (2014) Fear of recurrence in long-term breast cancer survivors-still an issue. Results on prevalence, determinants, and the association with quality of life and depression from the Cancer Survivorshipa multi-regional population-based study. Psycho-Oncology 23(5):547-554

9. Bower JE, Wiley J, Petersen L, Irwin MR, Cole SW, Ganz PA (2018) Fatigue after breast cancer treatment: biobehavioral predictors of fatigue trajectories. Health Psychol 37(11):1025

10. Bower JE (2014) Cancer-related fatigue-mechanisms, risk factors, and treatments. Nat Rev Clin Oncol 11(10):597

11. Gold M, Dunn LB, Phoenix B, Paul SM, Hamolsky D, Levine JD, Miaskowski C (2016) Co-occurrence of anxiety and depressive symptoms following breast cancer surgery and its impact on quality of life. Eur J Oncol Nurs 20:97-105

12. Montemurro F, Mittica G, Cagnazzo C, Longo V, Berchialla P, Solinas G, Culotta P, Martinello R, Foresto M, Gallizioli S (2016) Self-evaluation of adjuvant chemotherapy-related adverse effects by patients with breast cancer. JAMA Oncol 2(4):445-452

13. Ahn E, Cho J, Shin DW, Park BW, Ahn SH, Noh D-Y, Nam SJ, Lee ES, Yun YH (2009) Impact of breast cancer diagnosis and treatment on work-related life and factors affecting them. Breast Cancer Res Treat 116(3):609-616

14. Kilgour R, Vigano A, Trutschnigg B, Lucar E, Borod M, Morais J (2013) Handgrip strength predicts survival and is associated with markers of clinical and functional outcomes in advanced cancer patients. Support Care Cancer 21(12):3261-3270

15. Enright PL (2003) The six-minute walk test. Respir Care 48(8):783-785

16. Piccoli A, Rossi B, Pillon L, Bucciante G (1994) A new method for monitoring body fluid variation by bioimpedance analysis: the RXc graph. Kidney Int 46(2):534-539

17. Kumar S, Dutt A, Hemraj S, Bhat S, Manipadybhima B (2012) Phase angle measurement in healthy human subjects through bioimpedance analysis. Iran J Basic Med Sci 15(6): 1180

18. Norman K, Stobäus N, Zocher D, Bosy-Westphal A, Szramek A, Scheufele R, Smoliner C, Pirlich M (2010) Cutoff percentiles of bioelectrical phase angle predict functionality, quality of life, and mortality in patients with cancer. Am J Clin Nutr 92(3):612-619

19. Norman K, Stobäus N, Pirlich M, Bosy-Westphal A (2012) Bioelectrical phase angle and impedance vector analysis-clinical relevance and applicability of impedance parameters. Clin Nutr 31(6):854-861

20. Pappot H, Baeksted CW, Nissen A, Knoop A, Mitchell SA, Christensen J, Hjollund NH, Johansen C (2021) Clinical effects of assessing electronic patient-reported outcomes monitoring symptomatic toxicities during breast cancer therapy: a nationwide and population-based study. Breast Cancer. https://doi.org/10.1007/ s12282-021-01244-x

21. Kowalski C, Graeven U, von Kalle C, Lang H, Beckmann MW, Blohmer J-U, Burchardt M, Ehrenfeld M, Fichtner J, Grabbe S 
(2017) Shifting cancer care towards multidisciplinarity: the cancer center certification program of the German cancer society. BMC Cancer 17(1):1-9

22 Malecka-Massalska T, Chara K, Smolen A, Kurylcio A, Polkowski W, Lupa-Zatwarnicka K (2012) Bioimpedance vector pattern in women with breast cancer detected by bioelectric impedance vector analysis. Preliminary observations. Ann Agric Environ Med 19(4):697-700

23. Schmidt K, Vogt L, Thiel C, Jäger E, Banzer W (2013) Validity of the six-minute walk test in cancer patients. Int J Sports Med 34(07):631-636

24. Marroni CA, Miranda D, Boemeke L, Fernandes SA (2017) Phase angle bioelectrical impedance analysis (BIA) as a biomarker tool for liver disease. Biomarkers in Liver Disease (Biomarkers in Disease: Methods, Discoveries and Applications) Berlim: Springer Science:735-751

25. Stern AF (2014) The hospital anxiety and depression scale. Occup Med 64(5):393-394

26. Yellen SB, Cella DF, Webster K, Blendowski C, Kaplan E (1997) Measuring fatigue and other anemia-related symptoms with the functional assessment of cancer therapy (FACT) measurement system. J Pain Symptom Manage 13(2):63-74

27 Steiber N (2016) Strong or weak handgrip? Normative reference values for the German population across the life course stratified by sex, age, and body height. PloS one 11(10):e0163917

28. Bosy-Westphal A, Danielzik S, Dörhöfer RP, Later W, Wiese S, Müller MJ (2006) Phase angle from bioelectrical impedance analysis: population reference values by age, sex, and body mass index. J Parenter Enter Nutr 30(4):309-316

29. Enright PL, Sherrill DL (1998) Reference equations for the six-minute walk in healthy adults. Am J Respir Crit Care Med 158(5):1384-1387

30. Field A (2009) Discopering statistics using SPSS, 3rd edn. SAGE publications

31. Bakeman R (2005) Recommended effect size statistics for repeated measures designs. Behav Res Methods 37(3):379-384

32. Norman K, Wirth R, Neubauer M, Eckardt R, Stobäus N (2015) The bioimpedance phase angle predicts low muscle strength, impaired quality of life, and increased mortality in old patients with cancer. J Am Med Dir Assoc 16(2):173. e117-173. e122

33. Lee SY, Lee YJ, Yang J-H, Kim C-M, Choi W-S (2014) The association between phase angle of bioelectrical impedance analysis and survival time in advanced cancer patients: preliminary study. Korean J Fam Med 35(5):251

34. Barbosa-Silva MCG, Barros AJ (2005) Bioelectrical impedance analysis in clinical practice: a new perspective on its use beyond body composition equations. Curr Opin Clin Nutr Metab Care 8(3):311-317

35. Buffa R, Mereu R, Putzu P, Floris G, Marini E (2010) Bioelectrical impedance vector analysis detects low body cell mass and dehydration in patients with Alzheimer's disease. J Nutr Health Aging 14(10):823-827

36. Choi S-M, Lee S-H, Yang Y-S, Kim B-C, Kim M-K, Cho K-H (2001) 5-fluorouracil-induced leukoencephalopathy breast cancer. J Korean Med Sci 16:328-334

37. Cormier JN, Askew RL, Mungovan KS, Xing Y, Ross MI, Armer JM (2010) Lymphedema beyond breast cancer: a systematic review and meta-analysis of cancer-related secondary lymphedema. Cancer 116(22):5138-5149

38. Feliciano EMC, Chen WY, Lee V, Albers KB, Prado CM, Alexeeff S, Xiao J, Shachar SS, Caan BJ (2020) Body composition, adherence to anthracycline and taxane-based chemotherapy, and survival after nonmetastatic breast cancer. JAMA Oncol 6(2):264-270
39. Johansson K, Karlsson K, Nikolaidis P (2015) Evidence-based or traditional treatment of cancer-related lymphedema. Lymphology 48(1):24-27

40. Taetzsch A, Roberts SB, Bukhari A, Lichtenstein AH, Gilhooly CH, Martin E, Krauss AJ, Hatch-McChesney A, Das SK (2021) Eating timing: associations with dietary intake and metabolic health. J Acad Nutr Diet 121(4):738-748

41. Berger AM, Wielgus K, Hertzog M, Fischer P, Farr L (2010) Patterns of circadian activity rhythms and their relationships with fatigue and anxiety/depression in women treated with breast cancer adjuvant chemotherapy. Support Care Cancer 18(1):105-114

42. Celis-Morales CA, Welsh P, Lyall DM, Steell L, Petermann F, Anderson J, Iliodromiti S, Sillars A, Graham N, Mackay DF (2018) Associations of grip strength with cardiovascular, respiratory, and cancer outcomes and all cause mortality: prospective cohort study of half a million UK Biobank participants. Bmj 361

43 Wu Y, Wang W, Liu T, Zhang D (2017) Association of grip strength with risk of all-cause mortality, cardiovascular diseases, and cancer in community-dwelling populations: a meta-analysis of prospective cohort studies. J Am Med Dir Assoc 18(6):551. e517-551. e535

44. Miltenburg N, Boogerd W (2014) Chemotherapy-induced neuropathy: a comprehensive survey. Cancer Treat Rev 40(7):872-882

45 Corey B, Smania MA, Spotts H, Andersen M (2020) Young women with breast cancer: treatment, care, and nursing implications. Clin J Oncol Nurs 24(2):139-147

46. Cairney J, Dudley D, Kwan M, Bulten R, Kriellaars D (2019) Physical literacy, physical activity and health: toward an evidenceinformed conceptual model. Sports Med 49(3):371-383

47. Brown DM, Graham JD, Innes KI, Harris S, Flemington A, Bray SR (2020) Effects of prior cognitive exertion on physical performance: a systematic review and meta-analysis. Sports Med 50(3):497-529

48 Pei D-Q, Zhou H-M, Zhou Q-H (2019) Grip strength can be used to evaluate postoperative residual neuromuscular block recovery in patients undergoing general anesthesia. Medicine 98(2):e13940

49. Boing L, Vieira MdCS, Moratelli J, Bergmann A, de Azevedo Guimarães AC (2020) Effects of exercise on physical outcomes of breast cancer survivors receiving hormone therapy-a systematic review and meta-analysis. Maturitas

50. Cantarero-Villanueva I, Fernandez-Lao C, Fernández-DE-LasPeñas C, Díaz-Rodríguez L, Sanchez-Cantalejo E, ArroyoMorales M (2011) Associations among musculoskeletal impairments, depression, body image and fatigue in breast cancer survivors within the first year after treatment. Eur J Cancer Care 20(5):632-639

51. Bohannon RW (2015) Muscle strength: clinical and prognostic value of hand-grip dynamometry. Curr Opin Clin Nutr Metab Care 18(5):465-470

52. Santa Mina D, Brahmbhatt P, Lopez C, Baima J, Gillis C, Trachtenberg L, Silver JK (2017) The case for prehabilitation prior to breast cancer treatment. PM\&R 9(9):S305-S316

53. Kehmeier ES, Sommer MH, Galonska A, Zeus T, Verde P, Kelm M (2016) Diagnostic value of the six-minute walk test (6MWT) in grown-up congenital heart disease $(\mathrm{GUCH})$ : Comparison with clinical status and functional exercise capacity. Int J Cardiol 203:90-97

54. Islam T, Dahlui M, AbdMajid H, Nahar AM, Taib NAM, Su TT (2014) Factors associated with return to work of breast cancer survivors: a systematic review. BMC Public Health 14(3):1-13

55. Scott JM, Thomas SM, Peppercorn JM, Herndon JE, Douglas PS, Khouri MG, Dang CT, Yu AF, Catalina D, Ciolino C (2020) Effects of exercise therapy dosing schedule on impaired cardiorespiratory fitness in patients with primary breast cancer: a randomized controlled trial. Circulation 141(7):560-570 
56. Montan I, Löwe B, Cella D, Mehnert A, Hinz A (2018) General population norms for the functional assessment of chronic illness therapy (FACIT)-fatigue scale. Value Health 21(11):1313-1321

57. Abrahams H, Gielissen M, Verhagen C, Knoop H (2018) The relationship of fatigue in breast cancer survivors with quality of life and factors to address in psychological interventions: a systematic review. Clin Psychol Rev 63:1-11

58. Pereira PTVT, Reis AD, Diniz RR, Lima FA, Leite RD, da Silva MCP, Guerra RNM, de Moraes Vieira ÉB, Garcia JBS (2018) Dietary supplements and fatigue in patients with breast cancer: a systematic review. Breast Cancer Res Treat 171(3):515-526

59. Dong B, Xie C, Jing X, Lin L, Tian L (2019) Yoga has a solid effect on cancer-related fatigue in patients with breast cancer: a meta-analysis. Breast Cancer Res Treat 177(1):5-16

60. Juvet L, Thune I, Elvsaas IØ, Fors E, Lundgren S, Bertheussen G, Leivseth G, Oldervoll L (2017) The effect of exercise on fatigue and physical functioning in breast cancer patients during and after treatment and at 6 months follow-up: a meta-analysis. Breast 33:166-177
61. Lueboonthavatchai P (2007) Prevalence and psychosocial factors of anxiety and depression in breast cancer patients. J Med Assoc Thai 90(10):2164

62. Watson M, Homewood J, Haviland J, Bliss JM (2005) Influence of psychological response on breast cancer survival: 10-year followup of a population-based cohort. Eur J Cancer 41(12):1710-1714

63. Munir F, Kalawsky K, Lawrence C, Yarker J, Haslam C, Ahmed $S$ (2011) Cognitive intervention for breast cancer patients undergoing adjuvant chemotherapy: a needs analysis. Cancer Nurs 34(5):385-392

64. Hashemi S-M, Balouchi A, Al-Mawali A, Rafiemanesh H, RezaieKeikhaie K, Bouya S, Dehghan B, Farahani MA (2019) Healthrelated quality of life of breast cancer patients in the Eastern Mediterranean region: a systematic review and meta-analysis. Breast Cancer Res Treat 174(3):585-596

Publisher's note Springer Nature remains neutral with regard to jurisdictional claims in published maps and institutional affiliations. 